\title{
Statystyczna ocena zgodności wyników wyznaczania liczby metanowej paliw gazowych różnymi metodami
}

\begin{abstract}
W artykule przedstawiono ocenę przydatności różnego typu algorytmów służących do obliczania liczby metanowej paliw gazowych. Ocenę przydatności poszczególnych metod obliczeniowych przeprowadzono na podstawie uzyskanych wartości wskaźnika z-score. Podczas obliczeń uwzględniono zróżnicowany skład gazów palnych. Z tego względu obliczenia prowadzono dla gazu ziemnego, biogazu oraz gazów odpadowych. Uzyskane wyniki badań pozwoliły wskazać najbardziej uniwersalną metodę obliczania liczby metanowej oraz określić minimalną zawartość metanu, dla której prowadzenie obliczeń jest możliwe.
\end{abstract}

Słowa kluczowe: liczba metanowa, paliwa gazowe.

\section{Statistical evaluation of compliance of the results of gas methane determination using various methods}

The paper evaluates the suitability of various types of algorithms for calculating the methane number of gaseous fuels. The assessment of the suitability of individual calculation methods was based on the obtained z-score values. During calculations, the differentiated composition of flammable gases was taken into account. For this reason, calculations were made for natural gas, biogas and technological gas. The obtained results of the research allowed to indicate the most universal method for calculating the methane number and to determine the minimum methane content for which calculation is possible.

Key words: methane number, gaseous fuels.

\section{Wstęp}

Liczba metanowa jest istotnym parametrem charakteryzującym jakość gazu, gdyż określa odporność paliwa gazowego na spalanie stukowe, przy czym im większa wartość liczby metanowej, tym większa odporność paliwa na spalanie stukowe. Liczba metanowa to parametr bezwymiarowy, który ustalany jest w sposób analogiczny do liczby oktanowej dla benzyn. Podczas określania liczby metanowej paliw gazowych przyjęto dwa skrajne punkty: liczbę metanową czystego metanu, równą 100, i liczbę metanową wodoru, równą 0 . Liczba metanowa wyliczona jednym $z$ dostępnych algorytmów na podstawie składu gazu informuje o jakości analizowanego paliwa, w tym o możliwości jego zastosowania np. do napędu silników samochodowych lub urządzeń kogeneracyjnych. $Z$ tego względu zdefiniowanie dopuszczalnych zakresów liczby metanowej dla paliw gazowych jest istotne z punktu widzenia określenia możliwości ich wykorzystania. Mimo to obecnie brakuje wymagań prawnych w zakresie dopuszczalnych wartości liczby metano- wej gazu ziemnego rozprowadzanego sieciami gazowymi, biogazu zatłaczanego do sieci czy też gazu CNG wykorzystywanego w transporcie [26-28]. Natomiast jedynym dokumentem normalizacyjnym, który zawiera informacje dotyczące dopuszczalnej wartości liczby metanowej, jest norma [23], która definiuje, że gaz ziemny należący do grupy $\mathrm{H}$ powinien charakteryzować się liczbą metanową powyżej 65 . Również projekt normy prEN 16723-2 przewiduje wprowadzenie minimalnej liczby metanowej dla gazu ziemnego i biometanu stosowanego do napędu silników samochodowych. Zgodnie z tym projektem minimalna wartość liczby metanowej dla gazów wynosić będzie od 65 do 80 [8,25]. Przedstawione informacje wyraźnie pokazują, że problem dopuszczalnych wartości liczby metanowej paliw gazowych nie jest rozwiązany ani na poziomie odpowiednich uregulowań prawnych, ani norm międzynarodowych. Ze względu na brak uregulowań prawnych w zakresie dopuszczalnych wartości liczby metanowej informacje 
dotyczące optymalnej wartości tego parametru znaleźć można w doniesieniach literaturowych, wśród których dominuje pogląd, że optymalna wartość liczby metanowej dla gazów spalanych w silnikach wynosi powyżej 80 [4, 6, 13, 17-19]. Paliwo o liczbie metanowej powyżej 80 jest rekomendowane do silników samochodów ciężarowych z otwartą pętlą oraz silników pierwszej generacji z zamkniętą pętlą [17]. Za tym, że liczba metanowa paliw gazowych powinna być wyższa niż 80 , przemawia fakt, że gazy o niższej liczbie metanowej wpływać będą na efektywność pracy silników tłokowych, mogą również przyczyniać się do zwiększenia emisji szkodliwych substancji, a także zwiększać ich awaryjność $[6,13]$. Argumentem przeciw wprowadzeniu minimalnej liczby metanowej na poziomie 80 jest fakt, że tego rodzaju zapis wykluczyłby możliwość wykorzystania gazów LNG pochodzących z takich kierunków jak: Libia, Australia, Katar, Rosja, Algieria, Oman, Indonezja, Peru. Wymagań w zakresie liczby metanowej powyżej 80 nie spełnia również gaz ziemny wydobywany z obszaru Morza Północnego [6]. Dodatkowo istnieją doniesienia literaturowe [4], które mówią, że także gazy o mniejszej liczbie metanowej niż 80 mogą być z powodzeniem wykorzystywane w silnikach tłokowych. Rozwój technologii spowodował, że produkowane obecnie silniki dostosowane są do paliw o konkretnej zdefiniowanej liczbie metanowej, przy której charakteryzują się wysoką sprawnością, niskim zużyciem paliwa oraz niską emisją, np. silniki produkowane na rynek japoński są przystosowane do paliw gazowych o liczbie metanowej 65 [4]. Silniki o zapłonie iskrowym są w większości przystosowane do paliw o liczbie metanowej równej 70, przy czym spadek liczby metanowej do 65 spowodować może około 10-proc. spadek sprawności tych silników [10]. Dodatkowo istotny jest fakt, że w przypadku silników zoptymalizowanych do zasilania paliwem o danej liczbie metanowej (np. 90) zastosowanie paliwa o niższej liczbie metanowej skutkować będzie spalaniem stukowym, zjawiska takiego nie obserwuje się natomiast w przypadku paliw o wyższej liczbie metanowej [12]. Polskie doświadczenia w zakresie stosowania gazów o niskiej liczbie metanowej wskazują, że dla gazów o liczbie metanowej około 55 sprawność elektryczna silnika jest 7\% niższa niż dla gazów o liczbie metanowej równej 80 [13].

\section{Metody obliczania liczby metanowej}

Od czasu zdefiniowania liczby metanowej w latach 60 . dwudziestego wieku [10] powstały liczne algorytmy jej wyznaczania. Charakteryzują się one tym, że mogą dawać zróżnicowane wyniki obliczonej liczby metanowej, różniące się nawet o 7\%, dlatego też wartość liczby metanowej często podawana jest wraz z informacją o algorytmie, zgodnie z którym została wyznaczona [6].

Jeden z najprostszych algorytmów obliczania liczby metanowej opracował Gas Research Institute (GRI). Algorytm ten oparty jest na korelacji pomiędzy wartością liczby metanowej danego paliwa gazowego i wyznaczoną dla tego paliwa wartością motorowej liczby oktanowej (metoda 1) [2, 17, $22,24]$. W metodzie tej liczbę metanową wyznacza się zgodnie z równaniem (1):

$$
\mathrm{MN}=1,445 \cdot(\mathrm{MON})-103,42
$$

gdzie:

$\mathrm{MN}$ - liczba metanowa;

MON - motorowa liczba oktanowa.

W celu obliczenia na podstawie składu gazu motorowej liczby oktanowej można zastosować jedno z dwóch podejść. Pierwsze z nich zakłada liniową zależność motorowej liczby oktanowej od stężenia poszczególnych składników zawartych w gazie. Drugie podejście do wyznaczania motorowej liczby oktanowej na potrzeby obliczania liczby metanowej wykorzystuje stosunek reaktywnych atomów wodoru do węgla. Przy czym do określania stosunku wodór-węgiel nie są brane pod uwagę atomy węgla zawarte w związkach niepalnych, czyli np. w tlenku węgla(IV). Podczas wyznaczania liczby metanowej na podstawie motorowej liczby oktanowej zalecane jest zastosowanie obu podejść do wyznaczenia MON. Jeśli otrzymana na ich podstawie wartość liczby metanowej będzie się różnić o więcej niż 6 , wyniki należy odrzucić i zastosować inny algorytm obliczeniowy [2]. Algorytm polegający na wyznaczaniu liczby metanowej na podstawie oktanowej liczby motorowej jest bez wątpienia najprostszym algorytmem obliczeniowym, ma jednak liczne ograniczenia, wynikające między innymi z faktu, że algorytm obliczania MON na podstawie liniowej zależności nie uwzględnia występowania w gazie węglowodorów cięższych od butanu, tlenu, wodoru czy tlenku węgla(II). Natomiast algorytm obliczania MON na podstawie stosunku wodoru do węgla może być stosowany wyłącznie w przypadku gazów, dla których stosunek wodoru do węgla przekracza 2,5, a dodatkowo zawartość wszystkich składników niepalnych w gazie nie może przekraczać 5\% [17].

Kolejną metodą obliczania liczby metanowej jest metoda opracowana przez AVL (Anstalt für Verbrennungsmotoren Prof. H. List) w 1971 roku [1, 2, 4, 7, 22]. Do jej stworzenia w badaniach wykorzystano specjalny silnik testowy. Ze względu na trudne do dokładnego odtworzenia warunki pracy silnika stosowanego podczas badań wszystkie aktualizacje metody AVL oraz jej modyfikacje korzystają z oryginalnych danych z pierwszego algorytmu AVL [7]. 
Metoda AVL (metoda 2), służąca do obliczania liczby metanowej paliw gazowych, opiera się na wykorzystaniu danych uzyskanych dla dwu- i trójskładnikowych mieszanin gazowych zastosowanych w badaniach AVL. Dane te dostępne są w postaci diagramów [7]. Z tego względu w celu wyznaczenia liczby metanowej badanego gazu, którego skład określony jest w procentach objętościowych, wyjściowa mieszanina musi zostać podzielona na mieszaniny cząstkowe dwu- lub trójskładnikowe, dla których wyznaczane są cząstkowe liczby metanowe. Algorytm AVL uwzględnia jedynie takie składniki jak: metan, etan, propan, n-butan, tlenek węgla(IV) oraz azot, a węglowodory cięższe od propanu sumowane są jako n-butany. Podstawowy algorytm AVL ma liczne ograniczenia. Związane są one z jednej strony z tym, że nie uwzględnia on takich palnych składników gazowych jak: wodór, tlenek węgla(II) czy węglowodory nienasycone. Pozostałe ograniczenia algorytmu AVL wynikają z danych doświadczalnych zastosowanych podczas tworzenia tego algorytmu, w związku z czym metoda AVL nie może być stosowana do gazów zawierających powyżej 30\% tlenku węgla(IV) oraz powyżej 50\% azotu. Dodatkowo mieszanina gazowa zredukowana o składniki inertne po normalizacji powinna zawierać ponad $45 \%$ metanu.

Kolejną metodą wyznaczania liczby metanowej jest metoda firmy MWM (Motoren-Werke Mannheim) (metoda 3). Stanowi ona modyfikację podstawowej metody AVL [7, 10, 23]. Podobnie jak w przypadku metody AVL z wyjściowej mieszaniny gazowej eliminowane są gazy inertne, otrzymana mieszanina jest normalizowana, a następnie dzielona na mieszaniny cząstkowe i ponownie normalizowana. Jednak między metodami AVL a MWM istnieją również znaczące różnice [14]. Po pierwsze, węglowodory cięższe od propanu nie są bezpośrednio sumowane jako n-butany, lecz przeliczane do n-butanów przy użyciu odpowiednich współczynników. Dodatkowo mieszaniny cząstkowe tworzone są w taki sposób, aby każdy ze składników mieszaniny wyjściowej znajdował się w minimum dwóch mieszaninach cząstkowych. Jednak najważniejszą różnicą jest to, że liczby metanowe mieszanin cząstkowych nie są wyznaczane na podstawie diagramów opracowanych w metodzie AVL, lecz przy użyciu równań wielomianowych. Jedyne ograniczenia występujące w metodzie MWM dotyczą tworzenia trójskładnikowych mieszanin cząstkowych.

\section{Dobór optymalnej metody obliczania liczby metanowej - metodyka badań}

Wybór odpowiedniej metody obliczeniowej stosowanej do wyznaczania liczby metanowej paliw gazowych powinien uwzględniać zmienność składu paliw gazowych, źródła pochodzenia oraz procesy technologiczne, dla których liczba metanowa ma być wyznaczana. Do sprawdzenia poprawności działania poszczególnych algorytmów obliczeniowych wykorzystano rzeczywiste składy różnego typu paliw gazowych, uwzględniając ich zmienność $[9,21]$. Podczas obliczeń wzięto pod uwagę gazy ziemne należące do różnych grup, gaz z regazyfikacji LNG, biogaz, gazy pochodzące z procesów technologicznych, takie jak: wielkopiecowy, konwertorowy, koksowniczy, rafineryjny oraz gaz z odmetanowania kopalń. Podczas wyboru składu gazów do obliczeń założono, że poszczególne składy gazów powinny być jak najbardziej zróżnicowane, głównie pod względem zawartości metanu oraz wodoru, gdyż składnikom tym przypisane są odpowiednio liczby metanowe 100 i 0 [20]. Wybrane składy gazów do obliczeń zebrano $\mathrm{w}$ tablicy 1.

W celu oceny możliwości zastosowania dostępnych algorytmów wyznaczania liczby metanowej dla zróżnicowanych jakościowo paliw gazowych - przetestowano dostępne algorytmy (metody 1, 2 i 3) na wybranych do obliczeń składach gazów (G001-G030). Dodatkowo w obliczeniach użyto dwóch dostępnych on-line kalkulatorów służących do wyznaczania liczby metanowej (kalkulator 1 i kalkulator 2) [15, 16]. Kalkulator 1 wykorzystuje metodę obliczeniową opisaną w doku- mencie SAE 922359 [16], a więc metodę korelacji pomiędzy motorową liczbą oktanową a liczbą metanową. Kalkulator ten w obliczeniach uwzględnia występowanie takich składników jak: węglowodory $\mathrm{C}_{1}-\mathrm{C}_{10}$, wodór, tlen, azot, tlenek węgla(IV), tlenek węgla(II) oraz siarkowodór [16]. W przypadku kalkulatora 2 brak jest informacji o zastosowanym algorytmie obliczeniowym [15]. Podano jednak informacje, jakie są akceptowalne zawartości poszczególnych składników podczas prowadzenia obliczeń:metan może występować w zakresie od 70\% do 100\%, - etan, propan oraz wodór - od $0 \%$ do $30 \%$,

- tlenek węgla(IV) oraz azot - od $0 \%$ do $20 \%$,

- tlenek węgla(II) oraz węglowodory $\mathrm{C}_{4}-$ od $0 \%$ do $10 \%$,

- węglowodory $\mathrm{C}_{5}$ oraz węglowodory nienasycone - od $0 \%$ do $5 \%$,

- heksany - od $0 \%$ do $4,02 \%$,

- heptany - od $0 \%$ do $3,44 \%$,

- oktany - od $0 \%$ do $1,82 \%$.

Wymienione ograniczenia powodują, że kalkulator 2 nie może być stosowany do wyznaczania liczby metanowej gazu koksowniczego, gazu rafineryjnego oraz biogazu, a w niektórych przypadkach nawet gazów ziemnych zaazotowanych.

Komplet wyników uzyskanych dzięki zastosowaniu trzech metod obliczeniowych oraz dwóch kalkulatorów zebrano w tablicy 2 .

Analiza wyników otrzymanych metodą 1 wykazała, że w przypadku takich gazów jak gaz wielkopiecowy, konwertorowy 


\section{Hel}

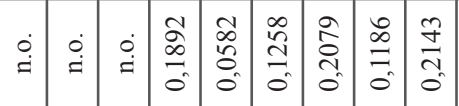

\section{Wodór}

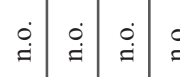

Tlenek węgla(II)

Tlen

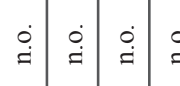

Tlenek węgla(IV)

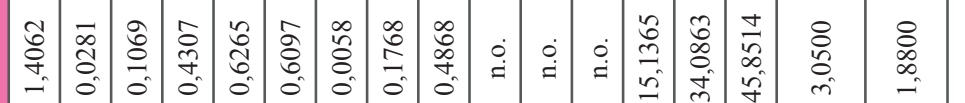

$\stackrel{a}{a}$

"ั.

$\frac{0}{3}$

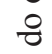

劳

है।

ఠิ

함

$0^{\circ}$

3

ป

帘 so

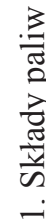

窇

n-butan

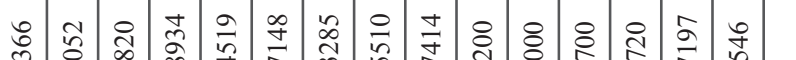

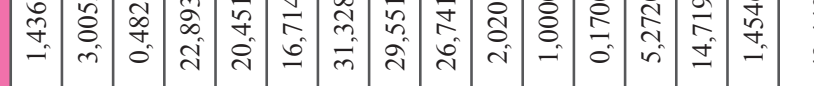

$\mathrm{C}_{6+}$

Neopentan

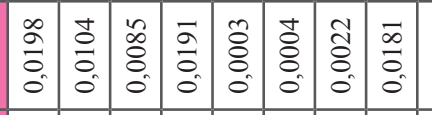

i-pentan

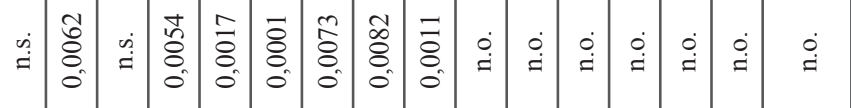

n-pentan

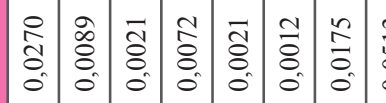


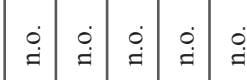
$\stackrel{\circ}{\dot{⿰}}$ $\stackrel{\dot{\square}}{=}$ $\stackrel{\circ}{\rightarrow}$

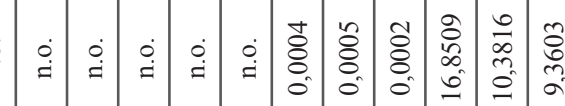

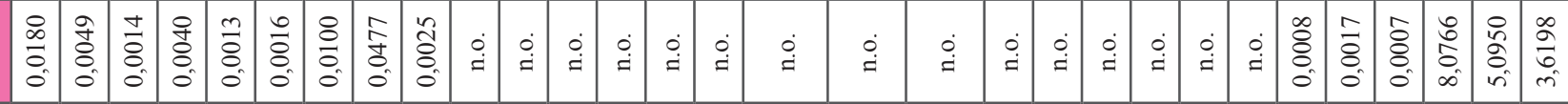

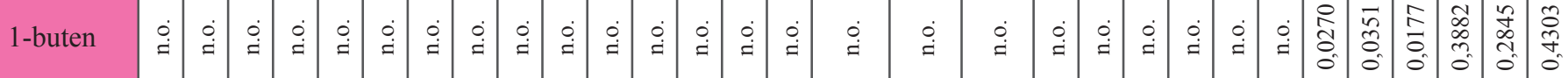

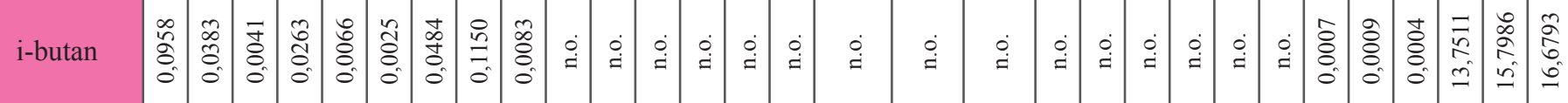

Propen

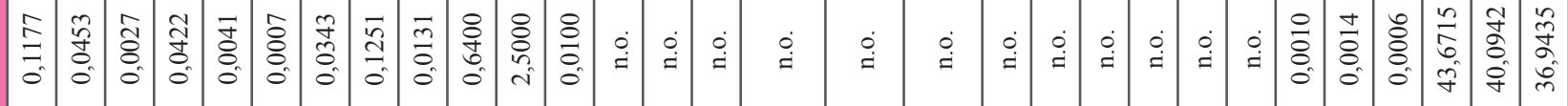

Propen

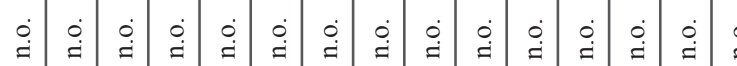

Propan

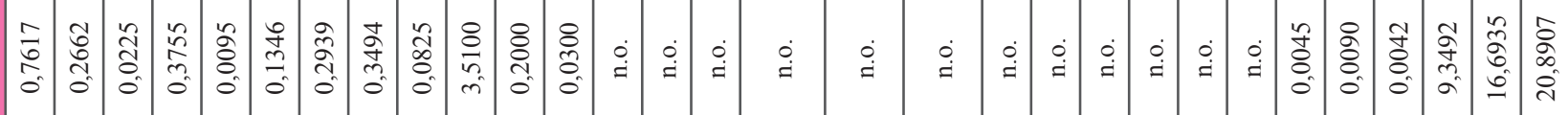

Eten

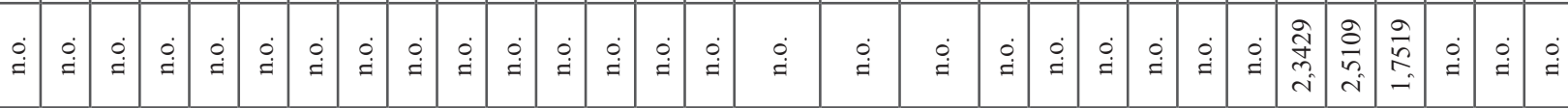

Etan

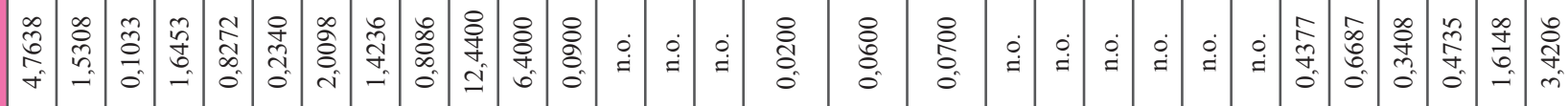

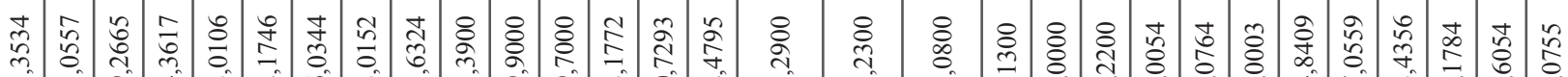

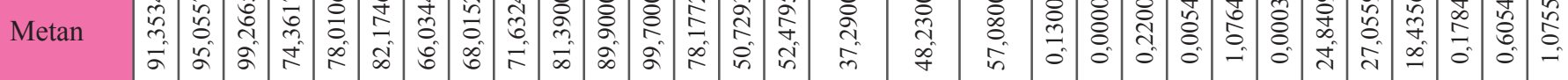

Rodzaj gazu

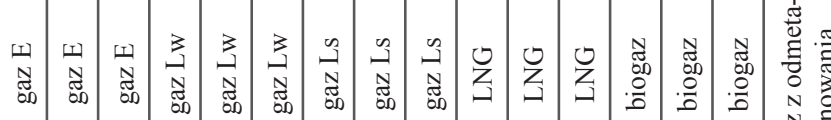

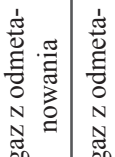

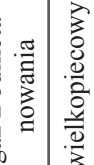

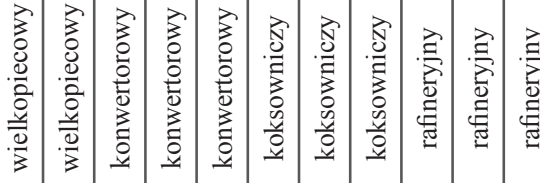

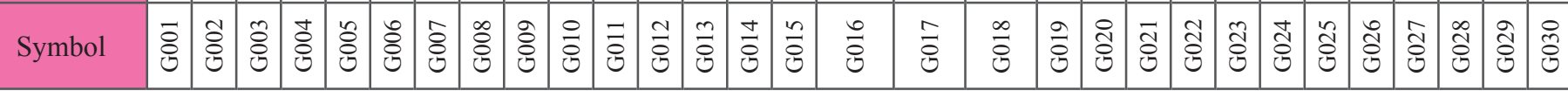


Tablica 2. Wyniki obliczeń liczby metanowej wykonanych dostępnymi metodami

\begin{tabular}{|c|c|c|c|c|c|c|}
\hline \multirow{2}{*}{$\begin{array}{c}\text { Symbol } \\
\text { gazu }\end{array}$} & \multirow{2}{*}{ Rodzaj gazu } & \multicolumn{5}{|c|}{ Liczba metanowa } \\
\hline & & metoda $1^{*}$ & metoda 2 & metoda 3 & kalkulator 1 & kalkulator 2 \\
\hline G001 & gaz ziemny E & 83,7 & 84,3 & 81,4 & 80,0 & 82,0 \\
\hline G002 & gaz ziemny $\mathrm{E}$ & 90,3 & 94,2 & 90,9 & 87,3 & 93,0 \\
\hline G003 & gaz ziemny E & 96,6 & 99,7 & 97,7 & 93,0 & 99,0 \\
\hline G004 & gaz ziemny Lw & 72,9 & 97,5 & 88,4 & 82,1 & 98,0 \\
\hline G005 & gaz ziemny Lw & 79,0 & 103,8 & 95,6 & 83,8 & 104,0 \\
\hline G006 & gaz ziemny Lw & 82,9 & 103,7 & 97,3 & 84,2 & 103,0 \\
\hline G007 & gaz ziemny Ls & 65,0 & 99,3 & 86,3 & 84,2 & 113,0 \\
\hline G008 & gaz ziemny Ls & 66,1 & 96,7 & 85,1 & 83,4 & 108,0 \\
\hline G009 & gaz ziemny Ls & 73,3 & 105,3 & 94,4 & 84,5 & 112,0 \\
\hline G010 & LNG & 63,6 & 67,2 & 65,3 & 67,4 & 68,0 \\
\hline G011 & LNG & 72,7 & 69,7 & 70,3 & 71,5 & 68,0 \\
\hline G012 & LNG & 96,9 & 99,5 & 97,9 & 94,2 & 99,0 \\
\hline G013 & biogaz & 96,5 & 117,4 & 121,3 & 107,1 & 107,0 \\
\hline G014 & biogaz & 95,8 & ND & 156,0 & 141,9 & 47,0 \\
\hline G015 & biogaz & 110,4 & ND & 163,7 & 147,5 & 88,0 \\
\hline G016 & gaz z odmetanowania kopalń & 48,5 & ND & 106,8 & 114,1 & $<46,8$ \\
\hline G017 & gaz z odmetanowania kopalń & 56,3 & ND & 102,0 & 94,9 & $<46,8$ \\
\hline G018 & gaz z odmetanowania kopalń & 63,9 & 119,0 & 101,9 & 87,7 & $<46,8$ \\
\hline G019 & gaz wielkopiecowy & $-358,8$ & ND & 366,4 & 261,4 & $<46,8$ \\
\hline G020 & gaz wielkopiecowy & $-298,5$ & ND & 255,6 & 366,5 & $<46,8$ \\
\hline G021 & gaz wielkopiecowy & $-317,2$ & ND & 308,1 & 382,5 & 70,0 \\
\hline G022 & gaz konwertorowy & $-368,1$ & ND & 416,2 & 204,5 & $<46,8$ \\
\hline G023 & gaz konwertorowy & $-343,7$ & ND & 196,0 & 132,1 & $<46,8$ \\
\hline G024 & gaz konwertorowy & $-372,2$ & ND & 349,9 & 129,4 & $<46,8$ \\
\hline G025 & gaz koksowniczy & 1372,9 & 89,4 & 26,2 & 29,1 & $<46,8$ \\
\hline G026 & gaz koksowniczy & 199,4 & 89,1 & 36,7 & 34,9 & $<46,8$ \\
\hline G027 & gaz koksowniczy & 186,6 & ND & 35,7 & 38,1 & $<46,8$ \\
\hline G028 & gaz rafineryjny & $-105,2$ & ND & 12,0 & 1,9 & $<46,8$ \\
\hline G029 & gaz rafineryjny & $-102,7$ & ND & 13,5 & 7,7 & $<46,8$ \\
\hline G030 & gaz rafineryjny & $-99,6$ & ND & 15,3 & 15,7 & $<46,8$ \\
\hline
\end{tabular}

ND - brak wyniku.

Kolorem czerwonym zaznaczono wyniki będące poza zakresem stosowalności danej metody.

*Wartość średnia z obliczeń liczby metanowej na podstawie liniowej zależności motorowej liczby oktanowej od stężenia poszczególnych składników zawartych w gazie oraz na podstawie stosunku wodoru do węgla.

oraz rafineryjny otrzymano ujemną liczbę metanową. Dla tych gazów uzyskano ujemne wartości motorowej liczby oktanowej obliczonej na podstawie zależności liniowej, a w przypadku gazu rafineryjnego również na podstawie składu gazu, ze względu na dużą zawartość węglowodorów $\mathrm{C}_{3}-\mathrm{C}_{4}$ w rozpatrywanym gazie. Zauważyć można także, że wartości liczby metanowej uzyskane metodą 1 dla gazu koksowniczego są znacznie wyższe niż wyniki otrzymane przy użyciu pozostałych metod. Jest to związane $\mathrm{z}$ niskim stosunkiem wodoru do węgla. Dodatkowo akceptowalną różnicę w wynikach obli- czeń liczby metanowej na podstawie liniowej zależności motorowej liczby oktanowej od stężenia poszczególnych składników zawartych w gazie oraz na podstawie stosunku wodoru do węgla uzyskano jedynie w przypadku takich gazów jak: gaz ziemny z grupy E, gazy LNG oraz jeden biogaz, czyli wyników obliczeń liczb metanowych mieszczących się w przedziale od 60,1 do 97,0. Można więc wnioskować, że metoda 1 ma zastosowanie wyłącznie do gazów o liczbie metanowej z tego przedziału. Analiza otrzymanych metodą 2 wyników obliczania liczby metanowej wykazała, że w przypadku 
takich gazów jak: biogaz, gaz wielkopiecowy, konwertorowy oraz gaz z odmetanowania kopalń nie było możliwe wyznaczenie wartości liczby metanowej ze względu na zbyt dużą zawartość składników inertnych, wykraczającą poza obszar diagramu metan, azot, tlenek węgla(IV). Natomiast w przypadku gazu rafineryjnego oraz jednego gazu zawierającego $28 \%$ propanu nie było możliwe wyznaczenie wartości liczby metanowej ze względu na to, że skład mieszanin cząstkowych wykraczał poza zakres diagramu metan, propan, butan i/lub diagramu metan, etan, butan. Uzyskane metodą 3 wartości liczby metanowej dla analizowanych gazów mieszczą się w zakresie od 12,0 do 416,2. Najniższe wartości, nieprzekraczające 20, uzyskano dla gazu rafineryjnego, natomiast najwyższe wartości liczby metanowej, przekraczające 200, otrzymano dla gazu wielkopiecowego oraz dwóch gazów konwertorowych. Zastosowanie kalkulatorów dostępnych on-line pozwoliło w przypadku kalkulatora 1 na uzyskanie wartości liczb metanowych w zakresie od 1,9 do 382,5. Najniższe wartości, nieprzekraczające 30, otrzymano dla gazu koksowniczego i rafineryjnego, natomiast najwyższe - przekraczające 200 - dla gazu wiel-

Tablica 3. Ocena uzyskanych wyników na podstawie wartości z-score

\begin{tabular}{|c|c|c|c|c|c|c|c|c|c|c|c|}
\hline \multirow{3}{*}{$\begin{array}{c}\text { Symbol } \\
\text { gazu }\end{array}$} & \multirow{3}{*}{$\begin{array}{l}\text { Rodzaj gazu } \\
\text { gaz ziemny E }\end{array}$} & \multicolumn{10}{|c|}{ Liczba metanowa } \\
\hline & & \multicolumn{2}{|c|}{ metoda 1} & \multicolumn{2}{|c|}{ metoda 2} & \multicolumn{2}{|c|}{ metoda 3} & \multicolumn{2}{|c|}{ kalkulator 1} & \multicolumn{2}{|c|}{ kalkulator 2} \\
\hline & & 0,6 & $\mathrm{Z}$ & 1,2 & $\mathrm{Z}$ & $-1,4$ & $\mathrm{Z}$ & 0,5 & $\mathrm{Z}$ & $-0,9$ & $\mathrm{Z}$ \\
\hline G002 & gaz ziemny E & $-0,4$ & $\mathrm{Z}$ & 1,3 & $\mathrm{Z}$ & $-0,1$ & $\mathrm{Z}$ & $-1,6$ & $Z$ & 0,8 & $Z$ \\
\hline G003 & gaz ziemny E & $-0,3$ & $\mathrm{Z}$ & 1,1 & $\mathrm{Z}$ & 0,2 & $\mathrm{Z}$ & $-1,8$ & $\mathrm{Z}$ & 0,8 & $\mathrm{Z}$ \\
\hline G004 & gaz ziemny Lw & $-1,6$ & $\mathrm{Z}$ & 1,0 & $\mathrm{Z}$ & 0,1 & $\mathrm{Z}$ & $-0,6$ & $\mathrm{Z}$ & 1,1 & Z \\
\hline G005 & gaz ziemny Lw & $-1,4$ & $\mathrm{Z}$ & 1,0 & $\mathrm{Z}$ & 0,2 & $\mathrm{Z}$ & $-0,9$ & $\mathrm{Z}$ & 1,1 & $\mathrm{Z}$ \\
\hline G006 & gaz ziemny Lw & $-1,3$ & $\mathrm{Z}$ & 1,1 & $\mathrm{Z}$ & 0,3 & $\mathrm{Z}$ & $-1,1$ & $\mathrm{Z}$ & 1,0 & $\mathrm{Z}$ \\
\hline G007 & gaz ziemny Ls & $-1,5$ & $\mathrm{Z}$ & 0,6 & $\mathrm{Z}$ & $-0,2$ & $\mathrm{Z}$ & $-0,3$ & $\mathrm{Z}$ & 1,5 & $\mathrm{Z}$ \\
\hline G008 & gaz ziemny Ls & $-1,6$ & $\mathrm{Z}$ & 0,6 & $\mathrm{Z}$ & $-0,2$ & $\mathrm{Z}$ & $-0,3$ & $\mathrm{Z}$ & 1,4 & $\mathrm{Z}$ \\
\hline G009 & gaz ziemny Ls & $-1,5$ & $\mathrm{Z}$ & 0,8 & $\mathrm{Z}$ & 0,0 & $\mathrm{Z}$ & $-0,7$ & $\mathrm{Z}$ & 1,3 & $\mathrm{Z}$ \\
\hline G010 & LNG & H-test & $\mathrm{N}$ & 0,2 & $\mathrm{Z}$ & $-1,7$ & $\mathrm{Z}$ & 0,4 & $\mathrm{Z}$ & 1,0 & $\mathrm{Z}$ \\
\hline G011 & LNG & 1,4 & Z & $-0,5$ & Z & $-0,1$ & Z & 0,7 & $\mathrm{Z}$ & $-1,5$ & Z \\
\hline G012 & LNG & $-0,3$ & $\mathrm{Z}$ & 1,1 & $\mathrm{Z}$ & 0,2 & $\mathrm{Z}$ & $-1,8$ & $\mathrm{Z}$ & 0,8 & $\mathrm{Z}$ \\
\hline G013 & biogaz & $-1,5$ & $\mathrm{Z}$ & 0,9 & $\mathrm{Z}$ & 1,3 & Z & $-0,3$ & $\mathrm{Z}$ & $-0,3$ & $\mathrm{Z}$ \\
\hline G014 & biogaz & $-0,3$ & $\mathrm{Z}$ & ND & $\mathrm{N}$ & 1,1 & $\mathrm{Z}$ & 0,7 & $\mathrm{Z}$ & $-1,5$ & Z \\
\hline G015 & biogaz & $-0,6$ & $\mathrm{Z}$ & ND & $\mathrm{N}$ & 1,2 & $\mathrm{Z}$ & 0,7 & $\mathrm{Z}$ & $-1,3$ & $\mathrm{Z}$ \\
\hline G016 & gaz z odmetanowania kopalń & H-test & $\mathrm{N}$ & ND & $\mathrm{N}$ & $\%$ & $\mathrm{Z}$ & $\%$ & $\mathrm{Z}$ & ND & $\mathrm{N}$ \\
\hline G017 & gaz z odmetanowania kopalń & H-test & $\mathrm{N}$ & ND & $\mathrm{N}$ & $\%$ & $\mathrm{Z}$ & $\%$ & $\mathrm{Z}$ & ND & $\mathrm{N}$ \\
\hline G018 & gaz z odmetanowania kopalń & $-1,4$ & $\mathrm{Z}$ & 1,3 & $\mathrm{Z}$ & 0,4 & $\mathrm{Z}$ & $-0,3$ & $\mathrm{Z}$ & ND & $\mathrm{N}$ \\
\hline G019 & gaz wielkopiecowy & ND & $\mathrm{N}$ & ND & $\mathrm{N}$ & $\%$ & $\mathrm{~N}$ & $\%$ & $\mathrm{~N}$ & ND & $\mathrm{N}$ \\
\hline G020 & gaz wielkopiecowy & ND & $\mathrm{N}$ & ND & $\mathrm{N}$ & $\%$ & $\mathrm{~N}$ & $\%$ & $\mathrm{~N}$ & ND & $\mathrm{N}$ \\
\hline G021 & gaz wielkopiecowy & ND & $\mathrm{N}$ & ND & $\mathrm{N}$ & 0,4 & $\mathrm{Z}$ & 1,0 & $\mathrm{Z}$ & $-1,4$ & $\mathrm{Z}$ \\
\hline G022 & gaz konwertorowy & ND & $\mathrm{N}$ & ND & $\mathrm{N}$ & $\%$ & $\mathrm{~N}$ & $\%$ & $\mathrm{~N}$ & ND & $\mathrm{N}$ \\
\hline G023 & gaz konwertorowy & ND & $\mathrm{N}$ & ND & $\mathrm{N}$ & $\%$ & $\mathrm{~N}$ & $\%$ & $\mathrm{~N}$ & ND & $\mathrm{N}$ \\
\hline G024 & gaz konwertorowy & ND & $\mathrm{N}$ & ND & $\mathrm{N}$ & $\%$ & $\mathrm{~N}$ & $\%$ & $\mathrm{~N}$ & ND & $\mathrm{N}$ \\
\hline G025 & gaz koksowniczy & H-test & $\mathrm{N}$ & 1,4 & $\mathrm{Z}$ & $-0,8$ & $\mathrm{Z}$ & $-0,7$ & $\mathrm{Z}$ & ND & $\mathrm{Z}$ \\
\hline G026 & gaz koksowniczy & H-test & $\mathrm{N}$ & 1,4 & $\mathrm{Z}$ & $-0,7$ & $\mathrm{Z}$ & $-0,7$ & $\mathrm{Z}$ & ND & Z \\
\hline G027 & gaz koksowniczy & H-test & $\mathrm{N}$ & ND & $\mathrm{N}$ & $\%$ & $\mathrm{Z}$ & $\%$ & $\mathrm{Z}$ & ND & Z \\
\hline G028 & gaz rafineryjny & ND & $\mathrm{N}$ & ND & $\mathrm{N}$ & $\%$ & $\mathrm{~N}$ & $\%$ & $\mathrm{~N}$ & ND & Z \\
\hline G029 & gaz rafineryjny & ND & $\mathrm{N}$ & ND & $\mathrm{N}$ & $\%$ & $\mathrm{~N}$ & $\%$ & $\mathrm{~N}$ & ND & $\mathrm{Z}$ \\
\hline G030 & gaz rafineryjny & ND & $\mathrm{N}$ & ND & $\mathrm{N}$ & $\%$ & $\mathrm{Z}$ & $\%$ & $\mathrm{Z}$ & ND & $\mathrm{Z}$ \\
\hline
\end{tabular}

ND - daną metodą nie można obliczyć liczby metanowej lub obliczona liczba metanowa była ujemna.

Z - wynik zadowalający.

$\mathrm{N}$ - wynik niezadowalający.

H-test - wartość liczby metanowej została odrzucona na podstawie testu Hampela.

\% - ocena wyniku przeprowadzona na podstawie różnicy pomiędzy wartością uzyskaną a wartością średnią. 
kopiecowego oraz jednego z gazów konwertorowych. Kalkulator 2, dostępny on-line, pozwala na wyznaczenie liczby metanowej, jeżeli przekracza ona 46,8. Z tego względu metoda nie znajduje zastosowania w przypadku gazu z odmetanowania kopalń, wielkopiecowego, konwertorowego, koksowniczego i rafineryjnego, a więc wszystkich gazów odpadowych.

Analiza wyników obliczeń liczby metanowej wykonanych różnymi metodami oraz przy użyciu kalkulatorów dostępnych on-line pozwala na wstępną ocenę metod. Jednak w celu wskazania najlepszej metody wyznaczania liczby metanowej dla próbek gazowych o zróżnicowanym składzie należy dokonać analizy otrzymanych wszystkimi metodami wyników z uwzględnieniem rodzaju i składu analizowanego gazu. Przed rozpoczęciem analizy z serii wyników obliczeń odrzucono ujemne wartości liczby metanowej, ze względu na brak fizycznej podstawy do przyjęcia tych wyników jako prawidłowych. Następnie dla każdego z analizowanych gazów serię danych sprawdzono testem Hampela pod kątem występowania wartości odstających. Wybór tego testu związany jest z faktem, że test ten cechuje się dużą czułością i nie wymaga, aby analizowana seria danych charakteryzowała się rozkładem normalnym. Dodatkowo dużą zaletą testu Hampela jest brak ograniczeń odnośnie do liczebności próby $[3,11,14]$. Po odrzuceniu wartości odstających zgodność pozostałych wyników wyznaczono, obliczając wartość wskaźnika z-score, przyjmując jako wartość rzeczywistą wartość średnią uzyskaną po odrzuceniu wartości odstających.

Podczas oceny otrzymanych wyników przyjęto następujące kryteria akceptacji [5]:

- $\quad \mathrm{IZI} \leq 2$ - wynik jest zadowalający $(\mathrm{Z})$,

- $2<$ IZI $<3$ - wynik jest wątpliwy (W),

- $3 \leq \mathrm{IZI}$ - wynik jest niezadowalający $(\mathrm{N})$.

W przypadku gdy po odrzuceniu wartości odstających w analizowanej serii danych pozostały dwie wartości (brak możliwości wyliczenia wskaźnika z-score), przyjęto, że uzyskany wynik uważany jest za zadowalający, jeżeli nie różni się od wartości średniej o więcej niż $\pm 5 \%$. Wyniki obliczeń wskaźnika z-score wraz z oceną przedstawiono w tablicy 3.

Analiza uzyskanych wyników obliczeń liczby metanowej dla gazu ziemnego wykazała, że dla każdego z analizowanych składów wyniki otrzymane wszystkimi metodami są zadowalające. W przypadku gazu LNG wynik uzyskany metodą 1 dla gazu oznaczonego symbolem G010 został odrzucony testem Hampela. To jedyny wynik niezadowalający otrzymany dla gazów LNG. Dla biogazu metody 1 i 3 oraz oba kalkulatory pozwoliły na uzyskanie 100\% wyników zadowalających. Wyjątek stanowiła metoda 2, którą nie udało się otrzymać wyników obliczeń liczby metanowej dla biogazów oznaczonych symbolami G014 i G015. Analiza wyników uzyskanych dla odpadowych gazów palnych pokazała, że:
- metoda 1 pozwoliła na otrzymanie jedynie 6,7\% wyników zadowalających, w pozostałych przypadkach wyniki były ujemne lub zostały odrzucone testem Hampela,

- metoda 2 dla 80\% analizowanych gazów nie pozwoliła na wyznaczenie liczby metanowej, w pozostałych 3 przypadkach uzyskano wyniki zadowalające,

- metodą 3 otrzymano 53,3\% wyników zadowalających, taki sam odsetek wyników zadowalających uzyskano, stosując pierwszy z kalkulatorów dostępnych on-line,

- dla 14 analizowanych gazów brak jest możliwości uzyskania wartości liczbowej liczby metanowej, otrzymać można jedynie informację, że liczba metanowa jest mniejsza od 46,8. Mimo to wszystkie wyniki wyznaczone za pomocą kalkulatora 2 dla gazu koksowniczego i rafineryjnego zostały uznane za zadowalające, gdyż średnia wartość liczby metanowej otrzymana pozostałymi metodami mieściła się w zakresie od 5,3 do 38,3, a więc była poniżej wartości 46,8. Optymalna metoda obliczeniowa służąca do wyznaczania liczby metanowej gazów palnych powinna przede wszystkim mieć zastosowanie do szerokiej gamy gazów palnych. Dlatego też podczas wyboru odpowiedniej metody w pierwszej kolejności przeanalizowano rozkład wyników zadowalających i niezadowalających uzyskanych poszczególnymi metodami, co zostało przedstawione na rysunku 1.

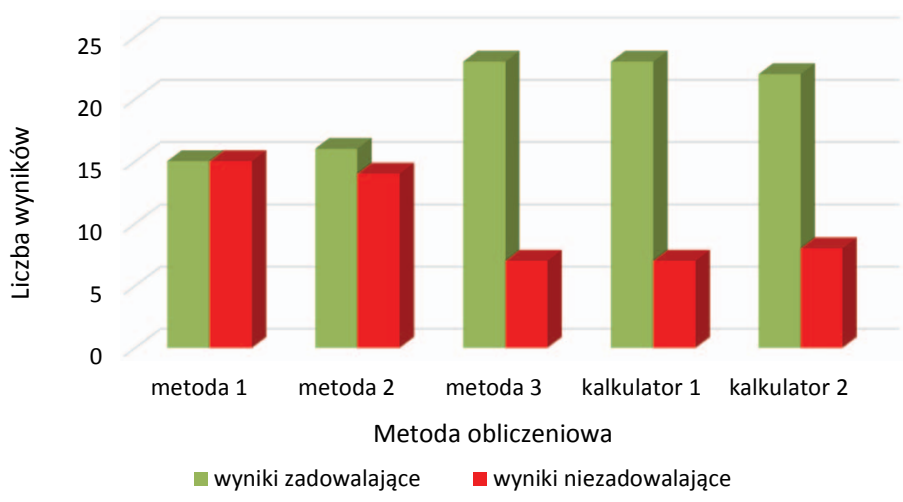

Rys. 1. Liczba wyników zadowalających i niezadowalających uzyskanych poszczególnymi metodami

Z danych przedstawionych na rysunku 1 wynika, że liczba wyników zadowalających uzyskanych poszczególnymi metodami jest zróżnicowana. Najmniejszą liczbę wyników zadowalających podczas obliczania liczby metanowej otrzymano, stosując metody 1 i 2 . Dla tych metod uzyskano odpowiednio 50,0\% oraz 53,3\% wyników zadowalających. Metodą 3 oraz przy użyciu kalkulatora 1 - po 23 wyniki zadowalające, co stanowi $76,7 \%$.

Na wybór właściwej metody obliczania liczby metanowej wpływa również odchylenie uzyskiwanych wyników od wartości średniej otrzymanej po odrzuceniu wartości odstających, co zostało przedstawione na rysunkach 2 i 3 . 


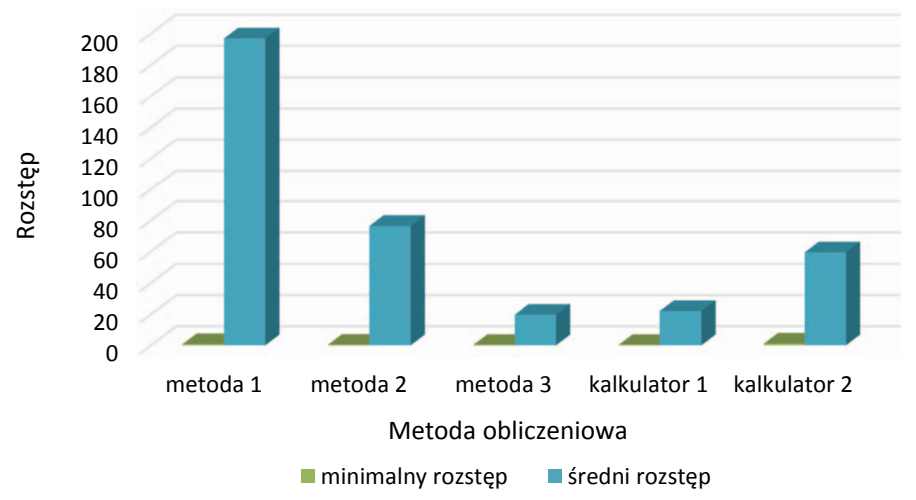

Rys. 2. Rozstęp pomiędzy średnimi wartościami liczby metanowej a wartościami wyznaczonymi daną metodą

Dane przedstawione na rysunkach 2 oraz 3 pokazują znacznie większe zróżnicowanie wyników uzyskiwanych dla poszczególnych metod. Dla wszystkich 30 analizowanych gazów minimalny rozstęp pomiędzy wartością średnią liczby metanowej a wartością uzyskaną poszczególnymi metodami mieścił się w przedziale od 0,1 (metoda 3) do 1,0 (kalkulator 2). Jednak już średnie wartości rozstępów są o wiele bardziej zróżnicowane i mieszczą się w przedziale od 19,5 (metoda 3 ) do 196,9 (metoda 1). Maksymalne odnotowane rozstępy znajdowały się w zakresie od 110 (metoda 3) do 1325 (metoda 1). Natomiast wartości sumaryczne uzyskanych rozstępów mieściły się w przedziale od 585 (metoda 3) do 5906 (metoda 1). Wyniki analiz danych przedstawionych na rysunkach 2 oraz 3 wykazują, że najmniej przydatna do wyznaczania liczby metanowej gazów palnych jest metoda 1 , natomiast najlepiej w tym zakresie sprawdza się metoda 3.

Ze względu na duży odsetek wyników niezadowalających w zakresie obliczania liczby metanowej palnych gazów odpadowych w kolejnym etapie przeanalizowano, jak rozkładają się liczby uzyskanych wyników niezadowalających w zależności od zawartości w gazie takich składników jak: metan, tlenek węgla(IV) oraz wodór. W pierwszej kolejności zbadano wpływ zawartości metanu, będącego głównym składnikiem palnym większości gazów, na rozkład wyników zadowalających i niezadowalających otrzymanych różnymi metodami (rysunek 4).

Analiza danych przedstawionych na rysunku 4 wyraźnie pokazuje, że procentowa zawartość metanu w analizowanym gazie ma wpływ na liczbę wyników zadowalających otrzymywanych podczas wyznaczania liczby metanowej (tablica 4).

Obliczanie liczby metanowej gazów palnych, które w swoim składzie zawierają mniej niż 5\% metanu (np. gaz wielkopiecowy i konwertorowy), nie powinno być prowadzone. Przemawia za tym fakt, że wyniki obliczeń liczby metanowej każdą z analizowanych metod były w większości niezadowalające. Gazy palne o zawartości metanu wynoszącej od $15 \%$ do $60 \%$ również przysparzają wielu trudności podczas obliczania liczby metanowej. Dla prowadzenia obliczeń w tym zakre-

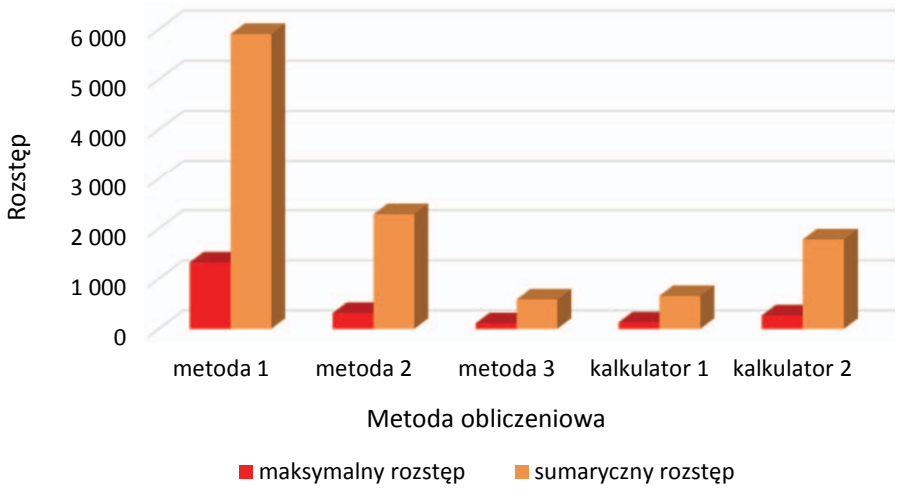

Rys. 3. Rozstęp pomiędzy średnimi wartościami liczby metanowej a wartościami wyznaczonymi daną metodą - cd.

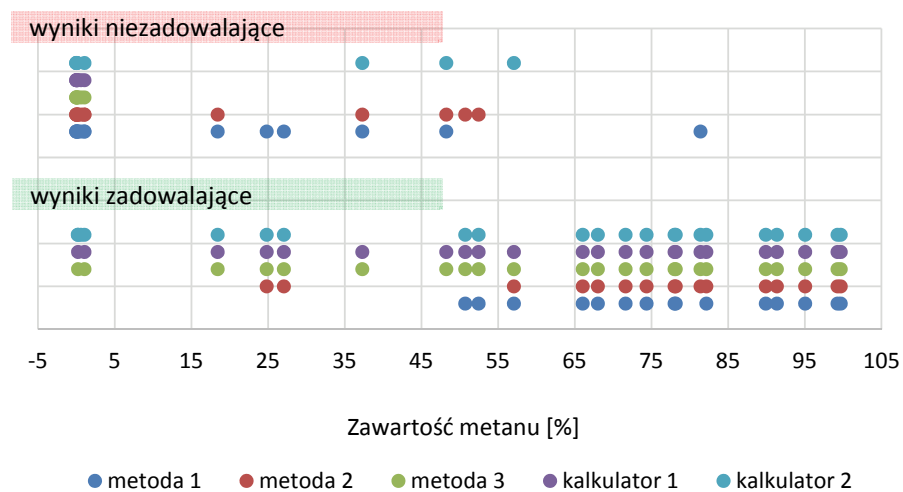

Rys. 4. Wpływ zawartości metanu na ocenę wartości liczby metanowej otrzymanej różnymi metodami

Tablica 4. Procentowy udział wyników niezadowalających w zależności od zawartości metanu

\begin{tabular}{|c|c|c|c|c|c|}
\hline \multirow{2}{*}{$\begin{array}{c}\text { Zawartość } \\
\text { metanu } \\
{[\%]}\end{array}$} & \multicolumn{4}{|c|}{ Udział procentowy wyników niezadowalających } \\
\cline { 2 - 6 } & metoda 1 & metoda 2 & metoda 3 & kalkulator 1 & kalkulator 2 \\
\hline$<5,0$ & 100,0 & 100,0 & 77,8 & 77,8 & 55,6 \\
\hline $15 \div 60$ & 62,5 & 62,5 & 0,0 & 0,0 & 37,5 \\
\hline $60 \div 100$ & 7,7 & 0,0 & 0,0 & 0,0 & 0,0 \\
\hline
\end{tabular}

sie rekomendowane jest zastosowanie metody 3 lub kalkulatora 1 . W przypadku gazów zawierających powyżej $60 \%$ metanu możliwe jest obliczanie liczby metanowej każdą z analizowanych metod, przy czym metoda 1 charakteryzuje się największym odsetkiem wyników niezadowalających, jednak nie przekracza on $10 \%$.

Następnym składnikiem, którego zawartość może wpływać na poprawność prowadzenia obliczeń liczby metanowej, jest wodór, gdyż przypisywana jest mu liczba metanowa równa 0 [20]. Wpływ zawartości wodoru na rozkład wyników zadowalających i niezadowalających uzyskanych różnymi metodami przedstawiono na rysunku 5.

Najwięcej trudności podczas obliczania liczby metanowej napotkano w przypadku gazów zawierających wodór w ilości od $0,1 \%$ do $2,0 \%$. Niezależnie od zastosowanej metody odsetek 
wyników niezadowalających wynosił od $83 \%$ do $100 \%$, należy jednak zwrócić uwagę na fakt, że w gazach tych występuje metan w ilości poniżej 2\%. Stąd też nieprawidłowe wyniki obliczeń liczby metanowej związane są nie tyle z zawartością wodoru w gazach, co z niską zawartością metanu.

Oprócz zawartości gazów palnych, takich jak np. metan, postanowiono sprawdzić również, jak na wyznaczone wartości liczby metanowej wpływa ilość inertów. Sprawdzenia tego dokonano na przykładzie tlenku węgla(IV); wpływ jego zawartości na poprawność obliczeń liczby metanowej przedstawiono na rysunku 6.

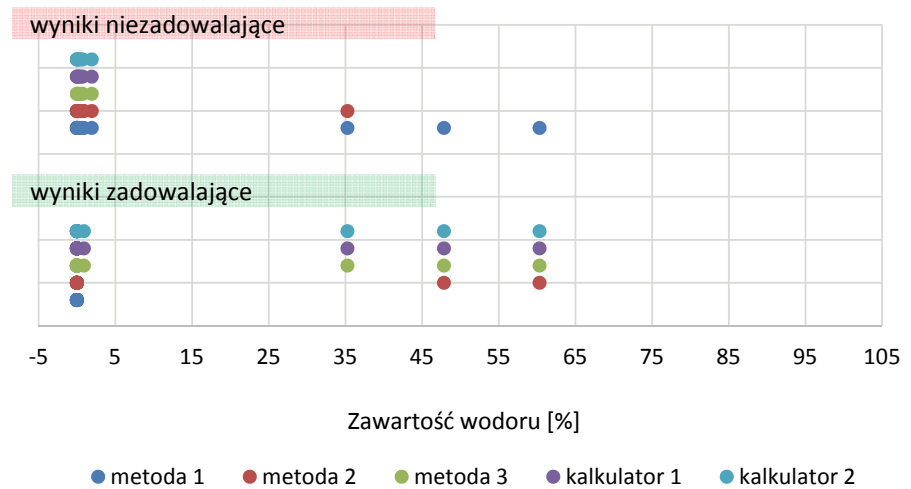

Rys. 5. Wpływ zawartości wodoru na ocenę wartości liczby metanowej otrzymanej różnymi metodami

Tablica 5. Procentowy udział wyników niezadowalających w zależności od zawartości wodoru

\begin{tabular}{|c|c|c|c|c|c|}
\hline \multirow{2}{*}{$\begin{array}{c}\text { Zawartość } \\
\text { wodoru } \\
{[\%]}\end{array}$} & \multicolumn{4}{|c|}{ Udział procentowy wyników niezadowalających } \\
\cline { 2 - 6 } & metoda 1 & metoda 2 & metoda 3 & kalkulator 1 & kalkulator 2 \\
\hline brak & 28,6 & 33,3 & 9,5 & 9,5 & 14,3 \\
\hline $0,1 \div 2$ & 100,0 & 100,0 & 83,3 & 83,3 & 83,3 \\
\hline $35 \div 65$ & 100,0 & 33,3 & 0,0 & 0,0 & 0,0 \\
\hline
\end{tabular}

Tlenek węgla(IV), jako składnik inertny, wpływa na poprawność wyznaczania liczby metanowej gazów. Największe trudności z prawidłowym określeniem liczby metanowej zauważyć można w przypadku gazów, dla których zawartość tlenku węgla(IV) mieści się w przedziale od 5\% do $15 \%$, przy czym są to gazy zawierające mniej niż $2 \%$ metanu. W przypadku gazów charakteryzujących się zawartością tlenku węgla(IV) poniżej 5\% rekomendowane jest stosowanie w obliczeniach metody 3 lub kalkulatora 1. Natomiast gdy zawartość tlenku węgla(IV) mieści się w przedziale od 15\% do 50\% zalecane jest również użycie kalkulatora 2.

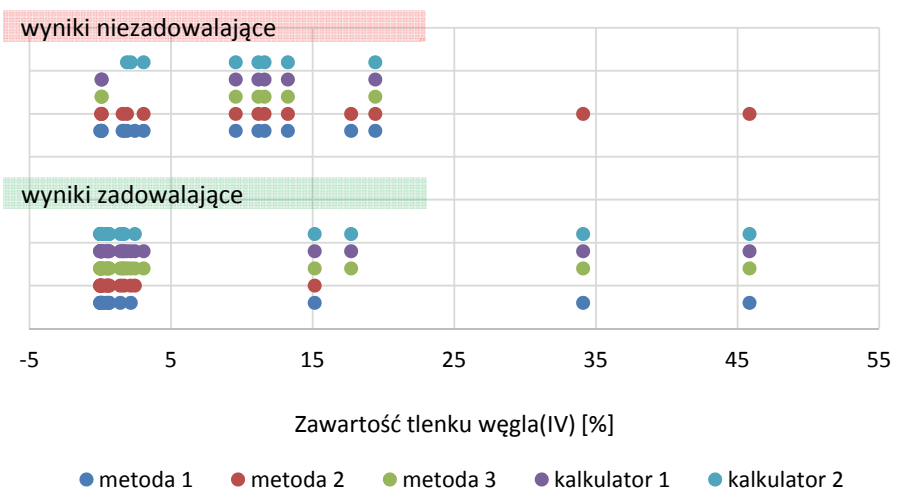

Rys. 6. Wpływ zawartości tlenku węgla(IV) na ocenę wartości liczby metanowej otrzymanej różnymi metodami

Tablica 6. Procentowy udział wyników niezadowalających w zależności od zawartości tlenku węgla(IV)

\begin{tabular}{|c|c|c|c|c|c|}
\hline \multirow{2}{*}{$\begin{array}{c}\text { Zawartość } \\
\text { tlenku } \\
\text { węgla(IV) } \\
{[\%]}\end{array}$} & \multicolumn{4}{|c|}{ Udział procentowy wyników niezadowalających } \\
\cline { 2 - 6 } & metoda 1 & metoda 2 & metoda 3 & kalkulator 1 & kalkulator 2 \\
\hline$<5 \%$ & 42,9 & 28,6 & 9,5 & 9,5 & 14,3 \\
\hline $5-15$ & 100,0 & 100,0 & 100,0 & 100,0 & 100,0 \\
\hline $15-50$ & 40,0 & 80,0 & 20,0 & 20,0 & 20,0 \\
\hline
\end{tabular}

\section{Wnioski}

Analizowane metody obliczeniowe można podzielić na metody oparte na motorowej liczbie oktanowej (metoda 1) oraz te wykorzystujące podział mieszaniny wyjściowej na dwu- lub trójskładnikowe mieszaniny cząstkowe (metody 2 i 3), a także na dostępne w sieci kalkulatory działające on-line (kalkulator 1 i 2), w przypadku których jednak nie zawsze wiadomo, jaki został w nich zastosowany algorytm obliczeniowy. Wyniki przeprowadzonych obliczeń liczby metanowej dla gazów charakteryzujących się zróżnicowanym składem pozwoliły stwierdzić, że najbardziej uniwersalną metodą obliczeniową jest metoda 3, dzięki której uzyskano 76,7\% wyników zadowalających. Taki sam odsetek wyników zadowalających otrzymano również podczas stosowania $\mathrm{w}$ obliczeniach kal- kulatora 1. Metoda 3 charakteryzuje się także najmniejszym średnim rozstępem uzyskanym pomiędzy wartościami wyznaczonymi tą metodą a wartościami średnimi, co potwierdza fakt, że metoda ta może być skutecznie stosowana do prowadzenia obliczeń liczby metanowej gazów palnych.

Analiza uzyskanych wyników z podziałem na rodzaj analizowanego gazu potwierdziła z kolei, że w przypadku zarówno gazów ziemnych, jak i gazów pochodzących z regazyfikacji LNG wybór metody obliczeniowej dla liczby metanowej wpływa na wynik w niewielkim stopniu. Oznacza to, że obliczenia dotyczące tych gazów mogą być prowadzone dowolną metodą. Natomiast w przypadku gazów odpadowych oraz biogazu widać wyraźne zróżnicowanie otrzymywanych 
wyników obliczeń liczby metanowej w zależności od zastosowanego algorytmu. Dodatkowym wnioskiem płynącym z analizy wyników obliczeń liczby metanowej różnymi metodami jest fakt, że obliczenia te nie powinny być prowadzone żad- ną z dostępnych metod dla gazów palnych, których zawartość metanu nie przekracza 5\%. Dlatego też rozwój metod obliczeniowych liczby metanowej powinien koncentrować się na opracowaniu algorytmów uwzględniających tego typu gazy.

Prosimy cytować jako: Nafta-Gaz 2018, nr 4, s. 298-307, DOI: 10.18668/NG.2018.04.06

Artykuł nadesłano do Redakcji 24.11.2017 r. Zatwierdzono do druku 7.03.2018 r.

Artykuł powstał na podstawie pracy statutowej pt.: Obliczanie liczby metanowej gazu jako element oceny jakości paliw - praca INiG - PIB na zlecenie MNiSW; nr zlecenia: 0069/GE/17/01, nr archiwalny: DK-4100-0056/17.

\section{Literatura}

[1] Andersen P.: Algorithm for methane number determination for natural gases. DGC Project Report 1999, s. 2-11.

[2] Arrhenius K., Kühnemuth D., Yaghooby H., Ohlson L.: Method development for gas quality determination in the LNG storage of a LNG/LCNG refueling station. SGC Rapport 2013, vol. 288, s. 17.

[3] Budka A., Kayzer D., Pietruszczyk K., Szoszkiewicz K.: Zastosowanie wybranych procedur do wykrywania obserwacji nietypowych w ocenie jakości rzek. Infrastruktura i Ekologia Terenów Wiejskich 2013, nr 3/II, s. 85-95.

[4] CIMAC: Impact of Gas Quality on Gas Engine Performance. CIMAC Position Paper, 07-2015, s. 8.

[5] Dobecki M., Wziątek A.: Badania biegłości jako wskaźnik jakości w laboratoriach wykonujacych pomiary czynników szkodliwych w środowisku pracy. Medycyna Pracy 2016, vol. 67, nr 2, s. 267-283.

[6] GIE: GIE Position Paper on impact of including Methane Number in the European Standard for Natural Gas. 12GIE127, November 2012, s. 5.

[7] Gieseking B., Brown A.S.: Novel algorithm for calculating the methane number of liquefied natural gas with defined uncertainty. Fuel 2016, vol. 185, s. 932-940.

[8] GIIGNL: Position paper on the impact of including methane number in natural gas regulation. International Group of Liquefied Natural Gas Importers, 2012, s. 4.

[9] Klimek P.: Zattaczanie gazu składowiskowego do sieci dystrybucyjnej gazu ziemnego. Nafta-Gaz 2009, nr 5, s. 415-418.

[10] Kramer U., Ferrera M., Künne H., Moreira D.C., Magnusson I.: Natural Gas/Methane Fuels: European Automotive Fuel Quality and Standardization Requirements. Erdgas 2015, s. 11-13.

[11] Łach S.: Zmodyfikowana metoda iloczynu skalarnego stużaca do badania kierunku filtracji w zaporach ziemnych. Rozprawa doktorska, Akademia Górniczo-Hutnicza im. Stanisława Staszica, Wydział Geodezji Górniczej i Inżynierii Środowiska 2014, s. 60.

[12] Melenshek M., Olsen D.B.: Methane number testing of alternative gaseous fuels. Fuel 2009, vol. 88, s. 650-656.

[13] Olajossy A.: Nowe możliwości energetycznego wykorzystania gazów o niskiej zawartości metanu. Polityka Energetyczna 2005, t. 8, z. 1, s. 27-38.

[14] Słowik M., Bartkowiak M.: Elementy statystycznej analizy wyników pomiarów na przykładzie badań wybranych cech mieszanek mineralno-asfaltowych. Drogownictwo 2016, nr 7-8, s. 247-253.

[15] Strona internetowa: http://www.wartsila.com/products/marine-oilgas/gas-solutions/methane-number-calculator (dostęp: 26.01.2017).

[16] Strona internetowa: https://quickserve.cummins.com/gas_analysis_tool/index.html (dostęp: 26.01.2017).

[17] Strona internetowa: https://www.arb.ca.gov/regact/cng-lpg/appd. pdf (dostęp: 24.01.2017).

[18] Strona internetowa: https://www.arb.ca.gov/regact/cng-lpg/appe. doc (dostęp: 24.01.2017).

[19] Strona internetowa: https://www.eiseverywhere.com/file_uploads/b0307c255e2886cc007cdfb300ea6ab4_GasFamiliarization. pdf (dostęp: 24.01.2017).

[20] Wellinger A.: Green gas grids. Standardization of biomethane. WP3/D3.3, 2014, s. 14.

[21] Wojtowicz R.: Ocena gazu granicznego G21 pod kątem jego przydatności do określenia jakości spalania gazów ziemnych wysokometanowych pochodzacych z regazyfikacji LNG w urzadzeniach użytku domowego. Nafta-Gaz 2013, nr 8, s. 599-612.

\section{Akty prawne i normatywne}

[22] ISO/TR 22302:2014 Natural gas - Calculation of methane number.

[23] PN-EN 16726:2016 Infrastruktura gazowa. Jakość gazu. Grupa H.

[24] PN-EN ISO 15403-1:2010 Gaz ziemny, Gaz ziemny stosowany jako sprężone paliwo do pojazdów. Cześć 1: Określanie jakości.

[25] prEN 16723-2 Natural gas and biomethane for use in transport and biomethane for injection in the natural gas network. Part 2: Automotive fuel specifications.

[26] Rozporządzenie Ministra Energii z dnia 30 czerwca 2016 r. w sprawie wymagań jakościowych dla sprężonego gazu ziemnego (CNG) (Dz.U. z 2016 r. poz. 1094).

[27] Rozporządzenie Ministra Gospodarki z dnia 2 lipca 2010 r. w sprawie szczegółowych warunków funkcjonowania systemu gazowego (Dz.U. z 2010 r. Nr 133, poz. 891 z późn. zm.).

[28] Rozporządzenie Ministra Gospodarki z dnia 24 sierpnia 2011 r. w sprawie szczegółowego zakresu obowiązku potwierdzania danych dotyczących wytwarzanego biogazu rolniczego wprowadzonego do sieci dystrybucyjnej gazowej (Dz.U. z 2011 r. Nr 187, poz. 1117).

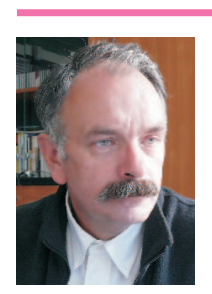

Mgr inż. Tadeusz SCHUSTER

Główny specjalista inżynieryjno-techniczny

w Zakładzie Ochrony Środowiska.

Instytut Nafty i Gazu - Państwowy Instytut Badawczy

ul. Lubicz 25 A

31-503 Kraków

E-mail: tadeusz.schuster@inig.pl

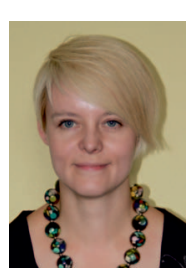

Mgr Jadwiga HOLEWA-RATAJ

Starszy specjalista badawczo-techniczny w Zakładzie Ochrony Środowiska.

Instytut Nafty i Gazu - Państwowy Instytut Badawczy ul. Lubicz $25 \mathrm{~A}$

31-503 Kraków

E-mail: jadwiga.holewa@inig.pl 